\title{
Teacher Competence in the Application of Social Science Learning Models
}

\author{
$1^{\text {st }}$ Sjamsi Pasandaran \\ Pancasila and Civic Education \\ Department \\ Universitas Negeri Manado \\ Manado, Indonesia \\ spasandaran@unima.ac.id
}

\author{
$4^{\text {th }}$ Theodorus Pangalila \\ Pancasila and Civic Education \\ Department \\ Universitas Negeri Manado \\ Tondano, Indonesia \\ theopangalila@unima.ac.id
}

\author{
$2^{\text {nd }}$ Deitje Adolfien Katuuk \\ Departemen of Elementary Schooler \\ Teacher \\ Universitas Negeri Manado \\ Tondano, Indonesia \\ deitjekatuuk@unima.ac.id \\ $5^{\text {th }}$ RR.Nanik Setyowati \\ Pancasila and Civic Education \\ Departement \\ Faculty of Sosial Sciences and Law \\ Universitas Negeri Surabaya \\ Surabaya, Indonesia \\ naniksetyowati@unesa.ac.id
}

\author{
$3^{\text {rd }}$ Julien Biringan \\ Departement of Pancasila dan Civics \\ Education \\ Faculty of Social Manado State \\ University \\ Manado, Sulawesi Utara \\ julienbiringan@unima.ac.id

$6^{\text {th }}$ Harmanto
Pancasila and Civic Education
Departement
Faculty of Sosial Sciences and Law
Universitas Negeri Surabaya
Surabaya, Indonesia
harmanto@unesa.ac.id

\begin{abstract}
This article investigates the weakness of the social science learning process, by examining teacher competencies in applying social science learning models. Using analytical descriptive methods, data collection was carried out through interviews, questionnaires, and observations of teachers, and the data were analyzed qualitatively statistically, using theories about teacher competencies and learning models. This study found the essential substance that became the weak point of teacher competence, namely low skill, creativity, and innovation in developing and implementing learning models. An important implication of the findings of this study is the need to change the paradigm of teacher education both preservice training and in-service training. This study recommends the need for a teacher education model that strengthens the formation of levels of good competence ability level, skill level, creativity level, and innovation level.
\end{abstract}

Keywords- the level of a teacher's competence, skill, creativity, innovation

\section{INTRODUCTION}

Weak teacher competencies are thought to be a factor in the weakness of the teacher's ability to develop various learning models, weaken the learning process, and also cause low student learning outcomes. Reference [1] found that teacher professional competence influences the instructional quality and student development, Mareike Kunter and Uta examined aspects of pedagogical content knowledge, professional beliefs, work-related motivation, and selfregulation as aspects of professional competence. Teacher competency turns out to also affect student learning performance [2]. Adnan Hakim examined aspects of pedagogic competence, professional competence, personality competence, and social competence. Reference [3] examined aspects of the influence of teacher professional competence on the ability to carry out the process of evaluating learning outcomes. Both of them examined aspects of qualitative assessment by teachers. Reference [4] found many weaknesses in teacher competency which lies in the management aspect of teacher professional development, that the development and effort to develop teacher competencies have not been able to improve the competence of teachers.

Various studies conducted, have not specifically examined the problem of teacher competence in developing learning models. This research was conducted to assess teacher competency in the application of social science learning models in schools. This study is useful to provide an overview of aspects of teacher competence both pedagogic competence and professional competence in the application of learning models. Understanding these aspects will greatly assist teachers in improving the effectiveness of the application of learning models. The results of the study will be useful for the development of science and technology about teacher competencies in the application of learning models and strengthen the pedagogical content of teacher education both pre-service and in-service training.

Studies of teacher competencies and learning models have been widely carried out. Teacher competencies and learning models are a cultural demand that continues to evolve along with the development of society, science, and technology. The concept of teacher competency, developed along with the development of thinking about the importance of competencies that developed since the Middle Ages, strengthened in the industrial community, and in the 21st century today [5]. Even so, teacher competence always 
points to aspects of knowledge, attitude, and skill. In Law No. 14 of 2005 concerning teachers and lecturers, it is required that a teacher must have competence in both pedagogic competence, professional competence, social competence, and personality competency. This study focuses on studies on the quality of teacher competencies seen in the level of teacher competency development, namely level one pedagogical ability, level two pedagogical skills, level three pedagogical creativity, and level 4 pedagogical innovation [6]. This study examines the level of teacher competency in applying learning models that refer to some of the model models that are relevant to social science learning namely thinking learning models [7], inductive learning models [8], contextual models learning [9] and information processing models[8].

It is empirically observed that teachers' understanding of various innovative learning models and the ability to apply various innovative learning models is still very limited. The teacher's knowledge of various learning models has not been followed by the teacher's ability to implement and develop various learning models into teaching practice. The practice of learning is still teacher-centered, monotonous, less contextual, and less encouraging for students' creativity. The problem that has not received much attention is the study of the teacher's ability, skill, creativity and innovation in the application of learning models. The study of teacher competence generally ignores the quality of the level of teacher competency in the development of learning models. This research will enrich the empirical understanding of the aspects of quality or level of competence needed in the development and application of learning models, and enrich a deeper theoretical understanding of teacher competency and the application of learning models. As an empirical study, this study provides an empirical scientific foundation regarding the policy of developing teacher professionalism through improving teacher competence.

\section{RESEARCH METHODS}

This research was carried out using the descriptive analytical method by describing and analyzing teacher competency levels in the application of learning models. These competency levels include (1) pedagogical ability level, (2) pedagogical skill level, (3) pedagogical creativity level, and (4) pedagogical innovation level. Data were collected from 30 social science teachers in public junior high schools in the city of Manado using instruments in the form of inventory of competency levels and analyzed using descriptive methods, with percentage calculation units.

\section{RESULTS AND DISCUSSION}

The findings of this study show a data description of the competency level for each model in table 1.

Table 1 Percentage of competency levels for each learning model

\begin{tabular}{|c|c|c|c|c|c|}
\hline \multirow{2}{*}{ Model } & \multicolumn{5}{|c|}{ Level of Competency } \\
\cline { 2 - 6 } & Ability & Skill & $\begin{array}{c}\text { Creativ } \\
\text { ity }\end{array}$ & $\begin{array}{c}\text { Innovat } \\
\text { ion }\end{array}$ & Total \\
\hline $\begin{array}{c}\text { Contextual } \\
\text { Teaching and } \\
\text { Learning }\end{array}$ & $73.33 \%$ & $20.00 \%$ & $3.33 \%$ & $3.33 \%$ & 100 \\
\hline Inquiry & $66.67 \%$ & $23.33 \%$ & $6.67 \%$ & $3.33 \%$ & $100 \%$ \\
\hline $\begin{array}{c}\text { Problem } \\
\text { Based }\end{array}$ & $66.67 \%$ & $23.33 \%$ & $6.67 \%$ & $3.33 \%$ & $100 \%$ \\
\hline
\end{tabular}

\begin{tabular}{|c|c|c|c|c|c|}
\hline Learning & & & & & \\
\hline $\begin{array}{c}\text { Cooperative } \\
\text { learning }\end{array}$ & $70.00 \%$ & $20.00 \%$ & $6.67 \%$ & $3.33 \%$ & $100 \%$ \\
\hline Average & $69.17 \%$ & $21.66 \%$ & $5.84 \%$ & $3.33 \%$ & $100 \%$ \\
\hline
\end{tabular}

The data in table 1 shows the first description that the average teacher competency is at the level of ability as much as $69.17 \%$, followed by the skill in application by $21.66 \%$ of teachers, and $5.84 \%$ of teachers have creativity in applying the learning model, and as many as $3.33 \%$ of teachers who have innovation in implementing and developing learning models. Second, it seems that teacher's ability towards learning models is not followed by skill, creativity, and innovation in applying and developing learning models. All models show a high ability, but in terms of skills, creativity and innovation show a lack of ability. Ability level of teacher competence shows the translation aspect, namely the ability to understand and explain the highest learning models that are as much as $16.53 \%$, followed by the ability to interpret each model as much as $9.30 \%$, and the ability to extrapolate or develop understanding, concepts, and meanings of each model found in $15.7 \%$ of teachers. Ability, skill, creativity, and innovation of teachers in understanding, implementing, and developing learning models cover substantive aspects, namely planning, developing goals, developing teaching materials, developing learning media, and developing scenario learning including the syntax of each learning model.

The findings of this study indicate that the level of competence of teachers can explain more broadly and indepth about the ability of teachers to develop and implement learning models. The findings of this study can explain the weaknesses of the susceptibility of teacher competence in the development and application of learning models. These weaknesses are first, that the competencies of the teachers studied are still at the ability level. This level of ability is the lowest level of competency [6], which shows the level of teacher's understanding of pedagogical content namely understanding of students, understanding of learning basics, mastery of the content of learning content, mastery of learning strategies and methods, especially mastery of the model -learning model. Even so, the findings of this study provide information that teachers have good ability about pedagogical content that must be mastered by a teacher.

Theoretically, the level of ability possessed by teachers will have implications for teachers' skills in applying learning models. But the findings of this study indicate a theoretical gap. The ability of ability possessed by teachers is not followed by the skills, creativity, and innovation of teachers in developing and applying learning models. Theoretically knowledge, understanding, and theoretical mastery as thinking abilities will contribute to one's skills, creativity, and innovative abilities. Empirically practical, the findings of this study explain the susceptibility aspects which are the weak points of teacher competence, namely the low skills, creativity, and innovation of teachers in developing learning models. Teacher competency levels proposed by reference [6] have empirical reinforcement that can explain the weak points of teacher competence and challenges that must be faced by teacher education institutions, and the efforts of teacher development conducted by the government so far. 
Theoretical gaps and weaknesses in teacher competence strengthen various research results so far that teacher competencies have an influence on the learning process [1], and [2]. The findings of this study clarify the substantive aspects. from the influence of teacher competence, namely teacher weaknesses in developing learning processes ranging from learning planning, selection of media and learning strategies, development of learning syntax, classroom management, until the learning outcomes assessment process can be explained by the teacher's own level of competence, ability, creativity and innovation The findings of this study also reinforce the paradigm of education and learning in the 21 st century. The paradigm places skills, creativity, and innovation as the main elements as the core substance of competence. Critical thinking ability provides the basis for the development of creativity, and creativity gives for an innovation process.

Important implications of the findings of this study on the theoretical side provide a framework for developing teacher education, especially in the process of forming teacher competencies. Praxis of teacher education so far needs to be reexamined, and a teacher education model is developed that guarantees the formation of teacher competencies as a whole both in terms of ability, skill, creativity and the ability to develop learning innovations. The findings of this study also provide a basis for developing guidance and developing teacher competencies on an ongoing basis. It is necessary to develop a model of education and training by strengthening aspects of ability, skill, creativity, and innovation. Another important implication is that the levels of teacher competence can be a reference framework for measuring competencies and terms of reference for the development and development of competency improvement for teachers in office. This means that the findings of this study encourage the need to change the paradigm of thinking about teacher competencies, the process of forming competencies themselves, and measuring competencies themselves.

\section{CONCLUSION}

Teachers have a variety of competencies, especially seen from the level of competence they have. The level of teacher competence ability reflected in good knowledge, understanding, and mastery of pedagogical theory is not followed by high skill, creativity, and innovation. Teacher competency levels have implications for the development process and implementation of learning models. Education and training of teacher competencies on an ongoing basis can be more focused on improving the skills, creativity, and innovative abilities of teachers. The need for a paradigm shift in thinking about teacher competence, the process of establishing competencies, and measuring competencies.

\section{ACKNOWLEDGMENT}

Thank you to the Rector of Manado State University, the Dean of the Faculty of Social Sciences Unima, the organizing committee, and Atlantis press publisher.

\section{REFERENCES}

[1] M. Kunter, U. Klusmann, J. Baumert, D. Richter, T. Voss, and A. Hachfeld, "Professional competence of teachers: Effects on instructional quality and student development.," J. Educ. Psychol., vol. 105, no. 3, p. 805, 2013.

[2] A. Hakim, "Contribution of competence teacher (pedagogical, personality, professional competence and social) on the performance of learning," Int. J. Eng. Sci., vol. 4, no. 2, pp. 1-12, 2015.

[3] M. Ilanlou and M. Zand, "Professional Competencies of Teachers and the Qualitative Evaluation," Procedia-Social Behav. Sci., vol. 29, pp. 1143-1150, 2011.

[4] D. Katuuk, "Evaluasi Implementasi Manajemen Berbasis Sekolah Pada Sekolah Dasar di Kota Tomohon Sulawesi Utara," Universitas Negeri Jakarta, 2012.

[5] Y. Wilcox, "An initial study to develop instruments and validate the Essential Competencies for Program Evaluators (ECPE)," 2012.

[6] O. Nessipbayeva, "The Competencies of the Modern Teacher.," Bulg. Comp. Educ. Soc., 2012

[7] B. K. Beyer, Teaching thinking in social studies: Using inquiry in the classroom. Merrill Publishing Company, 1979.

[8] B. Joyce, M. Weil, and E. Calhoun, "Models of teaching," 2003.

[9] S. J. Sears, Introduction to contextual teaching and learning. Phi Delta Kappa Educational Foundation, 2003. 